\title{
Analisis Pengaruh Kualitas Website BackpakerJakarta Terhadap Kepuasan Pengguna Dengan Metode Webqual
}

\author{
${ }^{1}$ Ispandi, ${ }^{2}$ Rino Ramadan, ${ }^{3}$ Rahdian Kusuma Atmaja, ${ }^{4}$ Adjat Sudradjat \\ STMIK Nusa Mandiri, Universitas Bina Sarana Informatika, Universitas Bina Sarana Informatika, \\ Universitas Bina Sarana Informatika \\ Jakarta, Indonesia \\ ispandi.ipd@nusamandiri.ac.id, rino.rim@bsi.ac.id, rahdian.kusuma@bsi.ac.id, adjat.ajt@bsi.ac.id
}

\begin{abstract}
Abstrak
Penelitian ini dilatar belakangi sejauh mana website backpaker jakarta dapat bermanfaat dan diterima oleh pengguna, oleh sebab itu perlu diadakan suatu pengukuran kualitas website tersebut agar dapat mengetahui apakah diterima dengan baik bagi pengguna website backpaker jakarta. Kualitas website berdasarkan persepsi pengguna merupakan hal yang penting untuk dijadikan umpan balik terhadap pihak penyedia. Penelitian ini menggunakan metode webqual yaitu dengan dimensi kegunaan (usability), kualitas informasi (information quality), kualitas interaksi (interaction quality). Proses analisis digunakan tahapan penarikan sampel responden yang ada di wilayah komunitas backpaker jakarta. Tahapan berikutnya analisis data yang terdiri dari uji validitas, uji reliabilitas dan penilaian dengan skala likert. Dalam penilaian menggunakan skala likert digunakan 5 interval penilaian, yaitu Sangat Setuju, Setuju, Ragu-Ragu, Tidak Setuju, Sangat Tidak Setuju. Terdapat pengaruh Kegunaan dan Informasi secara simultan terhadap Interaksi adalah sebesar $0,015<$ 0,05 dan nilai f hitung $23.978>\mathrm{t}$ tabel 3,59, sehingga dapat di simpulkan bahwa H3 diterima yang berarti terdapat pengaruh Kegunaan dan Informasi terhadap Interaksi.
\end{abstract}

Kata Kunci - Webqual; Backpaker Jakarta; Skala Likert

\section{PENDAHULUAN}

Backpaker Jakarta memiliki website yaitu https://backpackerjakarta.com, website ini adalah website kumintas bacpaker jakarta, yaitu sebuah komunitas Travelling yang didirikan pada 5 April 2013 dan berpusat di Jakarta dan sekitaranya (Bogor, Tangerang, Bekasi dan Depok). Komunitas Backpacker Jakarta atau biasa disingkat dengan BPJ selalu melakukan travelling atau jalan-jalan kesetiap tempat wisata dengan menggunakan sistem Sharecost (patungan). Artinya semua biaya akan ditanggung oleh peserta yang ikut dan juga akan selalu ada rincian laporan pemasukan dan pengeluaran serta dana yang tersisa diinfokan di semua group BPJ.

Sejauh ini setelah layanan website ini diimplementasikan belum pernah dilakukan.

Penilaian mengenai kualitas website tersebut berdasarkan persepsi pengguna atau pengunjung website, sehingga pengelola website belum bisamenerima umpan balik tentang website tersebut. Untuk mengetahui seberapa besar kualitas website https://backpackerjakarta.com terhadap kepuasan pengguna, penulis menggunakan metode webqual untuk mengujinya. Metode Webqual merupakan salah satu metode atau teknik pengukuran kualitas website berdasarkan persepsi pengguna akhir. Webqual sudah mulai dikembangkan sejak tahun 1998 dan telah mengalami beberapa iterasi dalam penyusunan dimensi dan butir-butir pertanyaannya. 
Ada banyak penelitian tentang dimensi, ukuran dan atribut kualitas layanan elektronik dan skala yangberbeda telah diusulkan untuk mengukur kualitas

layanan situs web (Connolly et al., 2010). mengembangkan WEBQUAL 4.0, yang merupakan skala yang umum digunakan untuk mengukur kualitas situs web dari situs online (Pathania \&

Rasool, 2017).

Penelitian ini mencoba untuk melakukan analisis terhadap kualitas layanan website backpaker jakarta dengan tujuan untuk mengetahui perbedaan antara persepsi aktual dan harapan ideal penggunawebsite, dalam hal ini member backpaker jakarta. Manfaat yang dapat diperoleh dari penelitian ini adalah dapat memberikan bahan pertimbangan atau masukan kepada pihak manajemen yang mengelola website tentang tindakan apa yang harus dilakukan manajemen demi keberhasilan implementasi layanan website Backpaker Jakarta

\section{KAJIAN PUSTAKA}

Metode webqual (Chmielarz \& Zborowski, 2018) merupakan salah satu metode atau teknik suatu pengukuran tingkat kualitas website berdasarkan persepsi pengguna akhir. Webqual sendiri disusun berdasarkan penelitian pada tiga (3) area dimensi kualitas yaitu:

1. Dimensi Kualitas Pengguna (usability quality) merupakan dimensi yang mengukur kemudahan dalam menggunakan Web.

2. Dimensi Kualitas Informasi (Information Quality)merupakan dimensi yang mengukur kualitas informasi sebuah web dalam memenuhi kebutuhan informasi penggunanya.

3. Dimensi Kualitas Interaksi (Interaction Quality) merupakan dimensi yang mengukur kualitas interaksi seperti keamanan web dan personalisasi penggunanya. Instrumen WebQual menggunakan pendekatan perception dan importance dari pengguna.

Skala likert menurut (Sugiyono, 2016) sebagai berikut : "Skala Likert digunakan untuk mengukur sikap, pendapat dan persepsi seseorang atau sekelompok orang tentang fenomena sosial". Untuk setiap pilihan jawaban diberi 8 skor, maka responden harus menggambarkan, mendukung pernyataan untukdigunakan jawaban yang dipilih.

Dengan skala Likert, maka variabel yang akan diukur dijabarkan menjadi indikator variabel. Kemudian indikator tersebut dijadikan sebagai titik

tolak ukur menyusun item-item instrumen yang dapatberupa pertanyaan atau pernyataan.

Tabel 1. Skala Penilaian Likert

\begin{tabular}{|c|c|c|}
\hline No & Keterangan & Skor \\
\hline 1 & Sangat Setuju & 5 \\
\hline 2 & Setuju & 4 \\
\hline 3 & Ragu-ragu & 3 \\
\hline 4 & Tidak Setuju & 2 \\
\hline 5 & Sangat Tidak Setuju & 1 \\
\hline
\end{tabular}

\subsection{Populasi}

Menurut (Sugiyono, 2016) Populasi adalah wilayah generalisasi yang terdiri atas obyek/subyek yang mempunyai kualitas dan karakteristik tertentu yang ditetapkan oleh peneliti untuk dipelajari dan kemudian ditarik kesimpulannya. Jadi populasi bukanhanya orang, tetapi juga obyek dan benda-benda alamyang lain. Populasi juga bukan sekedar jumlah yang ada pada obyek/subyek yang dipelajari, tetapi meliputi seluruh karakteristik/sifat yang dimiliki oleh subyek atau obyek itu.

\subsection{Sampel}

Menurut (Sugiyono, 2016) adalah bagian dari jumlah dan karakteristik yang dimiliki oleh populasi tersebut. Bila operasi besar, dan peneliti tidak mungkin mempelajari semua yang ada pada populasi. 


\subsection{Teknik Penarikan Sampel}

Teknik sampling menurut (Sugiyono, 2016) adalah merupakan teknik pengambilan sampel. Untuk menentukan sampel yang akan digunakan dalam penelitian, terdapat berbagai teknik sampling yang digunakan.

1. Probability Sampling Probability sampling adalah teknik pengambilan sampel yang memberikan peluang yang sama bagi setiap unsur (anggota) populasi untuk dipilih menjadi anggota sampel. Teknik ini meliputi:

2. Simple random sampling Dikatakan simple (sederhana) karena pengambilan anggota sampel dari populasi dilakukan secara acak tanpa memperhatikan strata yang ada dalam populasiitu.

3. Proportionate stratified random sampling Teknik ini digunakan bila populasi mempunyai anggota/unsur yang tidak homogen dan berstrata secara proporsional

4. Disproportionate stratified random sampling Teknik ini digunakan untuk menentukan jumlah sampel, bila populasi berstrata tetapi kurangproporsional.

5. Cluster sampling Teknik sampling daerah digunakan untuk menentukan sampel bila obyek yang akan diteliti atau sumber data sangat luas.

6. Nonprobability Sampling Non probability sampling adalah teknik pengambilan sampel yang tidak memberi peluang/kesempatan sama bagi setiap unsur atau anggota populasi untuk dipilih menjadi sampel. Teknik sampel ini meliputi:

a. Sampling sistematis Sampling sistematis adalah teknik pengambilan sampel berdasarkan urutan dari anggota populasi yangtelah diberi nomor urut.

b. Sampling kuota Sampling kuota adalah teknik untuk menentukan sampel dari populasi yang mempunyai ciri-ciri tertentu sampai jumlah (kuota) yang diinginkan.

c. Sampling incidental Yaitu teknik penentuan sampel berdasarkan kebetulan, yaitu siapa saja yang secara kebetulan insidental bertemu dengan peneliti dapat digunakan sebagai sampel.

d. Sampling purposive Yaitu teknik penentuan sampel dengan pertimbangan tertentu.

e. Sampling jenuh Yaitu teknik penentuan sampel bila semua anggota populasi digunkan sebagai sampel.

f. Snowball sampling Yaitu teknik penentuan sampel yang mula-mula jumlahnya kecil, kemudian membesar.

\subsection{Analisis Regresi Liner Berganda}

Menurut (Zamani et al., 2016) suatu regresi merupakan metode yang digunakan untuk menentukan suatu hubungan sebab-akibat antar variable satu dengan yang yang lain. Uji regresi linier berganda dibagi menjadi dua, yakin uji $\mathrm{F}$ dan uji $\mathrm{T}$.

\subsection{Statistical Product and Service Solution SPSS}

Aplikasi SPSS (Statistical Product and Service Solution) menurut (Rahayu et al., 2018) adalah sebuah program aplikasi yang memiliki kemampuan analisis statistic cukup tinggi serta sistem manajemen data pada lingkungan grafis dengan menggunakan menu-menu deskriptif dan kotak-kotak dialog yang sederhana sehingga mudah untuk dipahami cara pengoperasiannya bahkan bagi orang yang tidakmengenal dengan baik teori statistik.

Tugas pengguna hanyalah (Wahyuni et al., 2017) mendesain variabel yang akan dianalisis,memasukkan data dan melakukan perhitungan dengan menggunakan tahapan yang ada pada menu yang tersedia setelah perhitungan selesai tugas pengguna ialah menafsir angka-angka yangdihasilkan olah SPSS. Proses penafsiran inilah yang jauh lebih penting daripada sekedar memasukkan angka dan menghitungnya. 


\section{METODE PENELITIAN}

\subsection{Tahap Persiapan Penelitian}

Tahap perencanaan (Dyatmika, 2018) adalah tahapan yang harus direncanakan saat akan melakukan penelitian, data yang akan direncanakan adalah :

\section{Studi Literatur}

Pada tahap persiapan penelitian dilakukan studi literature yang menghasilkan pengertian dan penjelasan dari masing-masing teori yang digunakan dalam melakukan penelitian. Dimana dapat dilihat dari landasan teori Webqual 4.0, Regresi, Uji Validitas, Uji Asumsi, Regresi, regresi linear berganti, uji F, Uji t, analisis korelasi ganda, analisis determinasi (R2) dan observasi.

\section{Tahap Pengumpulan Data}

Pada tahap pengumpulan data ini dilakukan untuk lebih mengetahui mengenai permasalahan yang diteliti. Dari data yang dikumpulkan akan dapat diketahui mengenai sistem yang digunakan pada saat ini. Data-data dapat diperoleh melalui wawancara langsung dan dengan cara melihat langsung dilapangan terhadap sistem yang sedangdigunakan.

\subsection{Instrumen Penelitian}

Pada penelitian yang digunakan untuk instrument penelitian yaitu kuesioner. Untuk menjelaskan langkah mendesain kuesioner akan dibahas pada sub bab berikut.

\section{Desain Kuesioner}

Kuesioner ini akan dirancang untuk menyusun pertanyaan yang dibuat untuk digunakan dalam pengaruh kualitas website terhadap kepuasanpengguna dengan beberapa tahapan, yaitu Kualitas Kegunaan (Usability) Dibuat untuk mengukur tingkat kemudahan website https://backpackerjakarta yangdigunakan.

a. Kualitas Informasi (Information Quality) Dibuat untuk mengukur tingkat kualitas informasiyang ditampilkan di https://backpackerjakarta.

b. Kualitas Interaksi (Interaction Quality)

Dibuat untuk mengukur tingkat kualitas interaksi antara pengguna dengan website https://backpackerjakarta dilihat dari kepercayaan pengguna dan empati.

\section{Pengukuran Variabel}

Pengukuran variabel dilakukan denganmenggunakan skala Likert. Prosedur pengukuransebagai berikut.

a. Responden diminta untuk menjawab pertanyaan- pertanyaan umum yang akan dipergunakan sebagai dasar apakah responden masuk kriteriaatau tidak.

b. Responden diminta untuk menjawab setiap butir pertanyaaan dengan memilih jawaban yang terdiri dari : Sangat Setuju (SS), Setuju (S), RaguRagu (RG), Tidak Setuju (TS), dan Sangat Tidak Setuju(STS).

c. Penilaian (scoring) untuk masing-masing memiliki nilai yang berbeda untuk jawaban Sangat Setuju (SS) diberikan nilai 5 dan seterusnya menurun sampai pada jawaban Sangat Tidak Setuju (STS) yang diberikan nilai.

\subsection{Metode Pengumpulan Data}

Dalam penelitian ini data dikumpulkan dengan cara riset lapangan. Riset lapangan dipergunakan untuk mengumpulkan data dari responden. Pengumpulan data di lapangan dilakukan dengan survei menggunakan kuesioner.

\subsection{Populasi dan Sampel Penelitian}

Tujuan utama penarikan sampel adalah untukmemperoleh informasi tentang populasi. Populasi yang digunakan dalam penelitian ini adalah penggunawebsite Backpaker Jakarta sejumlah 100 orang.

Teknik pengambilan sampel yang digunakan masuk ke dalam kategori probability sampling, maka teknik pengambilan sampel probability yang dipilih adalah teknik simple random sampling menggunakan 
table rumus slovin besaran sampel yang digunakan pada penelitian ini berjumlah 17 dengan tingkat kesalahan yang dikehendaki adalah $5 \%$ atau $\mathrm{d}=0,05$

\subsection{Uji Asumsi}

Dalam melakukan analisis regresi dilakukan pula uji asumsi klasik yang terdiri dari Multikolinearitas, Heteroskedastisitas, dan Autokorelasi. Selain itu pastinya diuji pula Normalitas Data sebagai syarat dalam melakukan analisis regresi :

a. Uji Normalitas Data

Uji Normalitas digunakan untuk mengetahui apakah data terdistribusi dengan normal atau tidak. Analisis regresi linear mensyaratkan bahwa data harus terdistribusi dengan normal. Uji ini dilakukan dengan metode Normal Probability Plots. Dasar pengambilan keputusan untuk mendeteksi kenormalan adalah jika data menyebar di sekitar garis diagonal dan mengikuti arah diagonal, maka model regresi memenuhi asumsi normalitas.

b. Uji Multikolinearitas

Multikolinearitas adalah keadaan dimana ada tidaknya hubungan atau korelasi antar variable independen atau variable bebas (multikolinearitas) dapat diketahui atau di deteksi dengan memanfaatkan statistic korelasi Variance Inflation Factor (VIF). dilakukan dengan melihat apakah nilai koefisien VIF untuk masing-masing variable independen lebih besar dari 10 atau tidak. Apabila nilai koefisien VIF untuk masing-masing variable independen lebih besar dari pada 10, maka variable tersebut diidentifikasikan memiliki gejala multi kolinearitas. Hipotesis yang akan diuji untuk dapat membuktikan ada tidaknya multikolinearitas antar variable bebas sebagai berikut :

$$
\begin{aligned}
& \text { Ho : Tidak terdapat hubungan antarvariable independen } \\
& \text { Ha : Terdapat hubungan antar variableindependen. }
\end{aligned}
$$

c. Uji Heteroskedastisitas

Uji Heteroskedastisitas adalah dengan metode Glejser Test yaitu dengan meregresikan variable bebas terhadap nilai absolut redualnya. Niali absolut residual diperoleh dengan cara menghitung nilai residual melalui penghitungan regresi antara variable independen dengan variable dependen.

\section{d. Uji Linearitas}

Cara dalam mengetahui apakah variabel independen dan variabel dependen menunjukkan hubungan yang linear atau tidak bisa dilakukan dengan cara membandingkan nilai signifikansi Linearity dengan signifikansi yang ditetapkan yaitu 0,05 .

1. Bila sig.linearity < 0,05 maka H0 diterima,yang berarti regresi linear.

2. Bila sig.linearity $\geq 0,05$ maka $\mathrm{H} 1$ ditolak,yang berarti regresi tidak linear.

\section{HASIL DAN PEMBAHASAN}

\subsection{Uji Validitas}

Uji validitas menggunakan nilai $r$ tabel dengan signifikansi 0,05 . Untuk nilai $r$ tabel dengan $n=20$ maka di dapat $r$ tabel sebesar 0.444, jadi jika nilai korelasi lebih dari nilai $r$ tabel maka item dianggap valid, sedangkan jika kurang dari batasan yang ditentukan maka item dianggap tidak valid.

Tabel 2. Tabel Hasil Validita 


\begin{tabular}{|c|c|c|c|}
\hline $\mathrm{y} 4$ & 0,793 & 0,444 & Valid \\
\hline $\mathrm{y} 5$ & 0,734 & 0,444 & Valid \\
\hline $\mathrm{y} 6$ & 0,841 & 0,444 & Valid \\
\hline $\mathrm{y} 7$ & 0,69 & 0,444 & Valid \\
\hline
\end{tabular}

\subsection{Uji Realibilitas Instrumen}

Untuk mengetahui apakah kuesioner tersebut reliable atau tidak, maka kuesioner tersebut diuji dengan metode alpha cronbach dengan SPSS. Hasil dariuji realibilitas dengan menggunakan SPSS untuk masing-masing dimensi dapat dilihat pada tabel berikut:

Tabel 3. Tabel Hasil Reliabilitas
\begin{tabular}{|l|l|}
\hline Variabel & Cronnbach Alpha \\
\hline Kualitas Kegunaan & 0,851 \\
\hline Kualitas Informasi & 0,733 \\
\hline $\begin{array}{l}\text { Kualitas Layanan } \\
\text { Interaksi }\end{array}$ & 0,881 \\
\hline
\end{tabular}

\subsection{Uji Asumsi Klasik}

A. Multikolinearitas

Tabel 4. Tabel Hasil Multikolinearitas

\begin{tabular}{|l|l|l|}
\hline Variabel & Tolerance & VIF \\
\hline Kualitas Kegunaan & 0,989 & 1,011 \\
\hline Kualitas Informasi & 0,953 & 1,049 \\
\hline $\begin{array}{l}\text { Kualitas Layanan } \\
\text { Interaksi }\end{array}$ & 0,997 & 1,003 \\
\hline
\end{tabular}

Dapat kita lihat nilai tolerance lebih dari 0,1 dan nilai VIF lebih kecil dari 10. Maka tidak terjadi multikolinearitas pada penelitian ini.

\section{B. Heterokedastisitas}

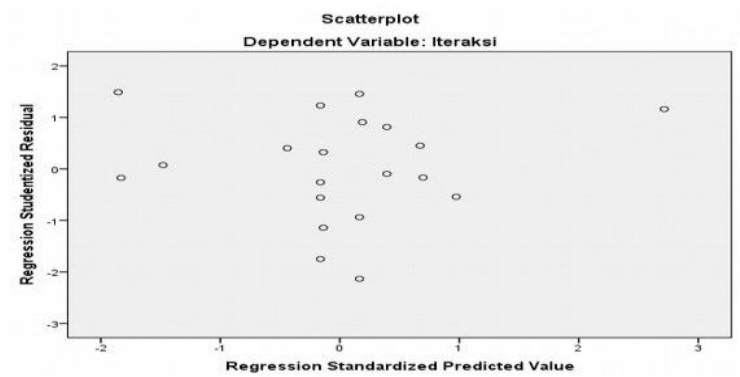

Gambar 1. Hasil Heterokedastisitas dengan ScatterPlot 


\begin{tabular}{|c|c|c|c|}
\hline $\begin{array}{l}\text { Item } \\
\text { pertanyaan }\end{array}$ & r hitung & $\mathrm{r}$ tabel & keterangan \\
\hline \multicolumn{4}{|c|}{ Usability (Kegunaan) } \\
\hline $\mathrm{x} 1.1$ & 0,801 & 0,444 & Valid \\
\hline $\mathrm{x} 1.2$ & 0,464 & 0,444 & Valid \\
\hline $\mathrm{x} 1.3$ & 0,634 & 0,444 & Valid \\
\hline $\mathrm{x} 1.4$ & 0,677 & 0,444 & Valid \\
\hline $\mathrm{x} 1.5$ & 0,638 & 0,444 & Valid \\
\hline $\mathrm{x} 1.6$ & 0,77 & 0,444 & Valid \\
\hline $\mathrm{x} 1.7$ & 0,494 & 0,444 & Valid \\
\hline $\mathrm{x} 1.8$ & 0,623 & 0,444 & Valid \\
\hline \multicolumn{4}{|c|}{ Information Quality (Kualitas Informasi) } \\
\hline $\mathrm{x} 2.1$ & 0,485 & 0,444 & Valid \\
\hline $\mathrm{x} 2.2$ & 0,604 & 0,444 & Valid \\
\hline $\mathrm{x} 2.3$ & 0,583 & 0,444 & Valid \\
\hline $\mathrm{x} 2.4$ & 0,536 & 0,444 & Valid \\
\hline $\mathrm{x} 2.5$ & 0,668 & 0,444 & Valid \\
\hline $\mathrm{x} 2.6$ & 0,497 & 0,444 & Valid \\
\hline $\mathrm{x} 2.7$ & 0,493 & 0,444 & Valid \\
\hline \multicolumn{4}{|c|}{ Quality of Interaction (Kualitas Interaksi) } \\
\hline $\mathrm{y} 1$ & 0,788 & 0,444 & Valid \\
\hline $\mathrm{y} 2$ & 0,616 & 0,444 & Valid \\
\hline $\mathrm{y} 3$ & 0,882 & 0,444 & Valid \\
\hline
\end{tabular}

\section{Autokorelasi}

Dari penelitian ini di dapat nilai Durbin Watson sebesar 1,129 dan dari tabel Durbin Watson signifikan 5\% di dapat nilai $\mathrm{dL}=1,1004 \mathrm{dU}=1,53674-\mathrm{dL}=2,89964-\mathrm{dU}=2,4633$. Sehingga dapat dinyatakan tidak terjadi autokorelasi karna memenuhisyarat $\mathrm{dL}<\mathrm{DW}<4-\mathrm{dU}(1,1004<1,129<2,4633)$.

\subsection{Normalitas Data}

Dapat dinyatakan model regresi pada penelitian ini memenuhi asumsi normalitas karena dilihat dari gambar dibawah ini data menyebar disekitar garis diagonal.

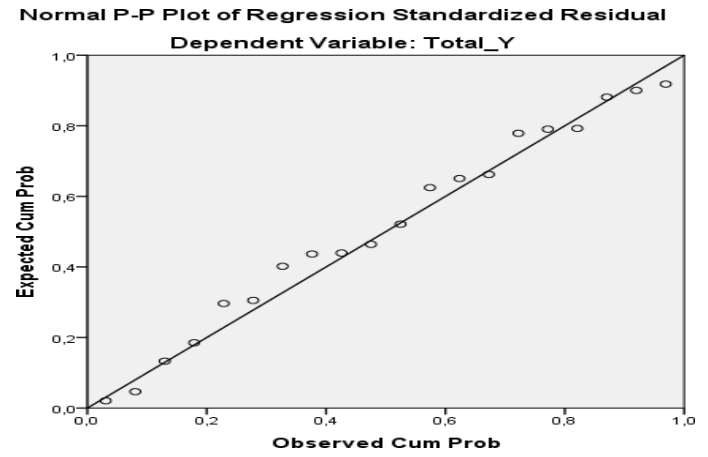

This is an Creative Commons License This work is licensed under a Creative Commons AttributionNonCommercial 4.0 International License. 
Gambar 2. Hasil Normalitas Data dengan NormalProbability Plots

\subsection{Uji T dan Uji F}

\section{A. Uji T}

Uji statistik t pada dasarnya menunjukan seberapa jauh pengaruh satu variabel bebas (independent) secara partial atau individual dalam mempengaruhi variabel tidak bebas (dependent).

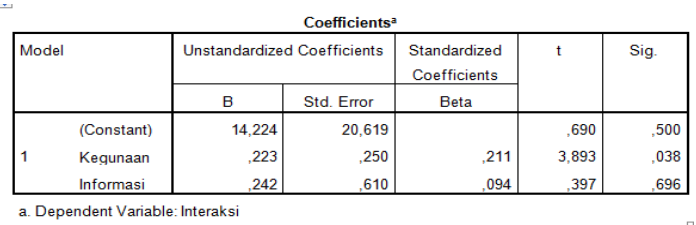

Perhatikan nilai Sig hasil uji $\mathrm{T}$ pada tabel

Coefficients diatas, didapatkan :

1. KEGUNAAN didapatkan $\mathrm{Sig}=0,038(\mathrm{sig}<0,05)$ artinya secara partial berpengaruh terhadap $\mathrm{Y}$

2. INFORMASI didapatkan Sig $=0,696($ sig $<0,05)$ artinya secara partial tidak berpengaruh terhadap $Y$ $\mathrm{t}$ tabel $=\mathrm{t}(\mathrm{a} / 2 ; \mathrm{n}-\mathrm{k}-1)=\mathrm{t}(\mathbf{0 , 0 2 5} ; 17)=2,1098$

\section{B. Uji F}

Uji statistik F pada dasarnya menunjukan apakah semua variabel bebas (independent) yang ada dalam model regresi mempunyai pengaruh secara bersama-sama atau simultan terhadap variabel tidak bebas (dependent).

\begin{tabular}{|c|c|c|c|c|c|c|}
\hline \multicolumn{7}{|c|}{ ANOVA $^{\mathrm{a}}$} \\
\hline Model & & Sum of Squares & df & Mean Square & $\mathrm{F}$ & Sig. \\
\hline \multirow{3}{*}{1} & Regression & 12,211 & 2 & 6,106 & 23,978 & $0,007^{b}$ \\
\hline & Residual & 207,789 & 17 & 12,223 & & \\
\hline & Total & 220,000 & 19 & & & \\
\hline
\end{tabular}

a. Dependent Variable: Interaksi

b. Predictors: (Constant), Informasi, Kegunaan

$F$ tabel $=F(k ; n-k)=t(2 ; 18)=3,59$

Pada tabel tersebut memaparkan uji kelinieran Ftest didapat nilai F hitung sebesar 23.978 dengan probabilitas 0.007. karena probabilitas jauh lebih kecil dari 0.05, maka model regresi dapat digunakan untuk memprediksi kepuasan pengguna website https://backpackerjakarta.com/atau dapat dikatakan bahwa semua variable independen secara simultanmemiliki pengaruh yang signifikan terhadap variabel Interaksi.

\section{IV.KESIMPULAN DAN SARAN}

Pada penelitian kali ini, ada 3 hipotesis sehinggadapat dianalisa bahwa:

1. Hipotesis pertama, Diketahui nilai Sig. untuk pengaruh Kegunaan terhadap Interaksi adalah sebesar $0,038<0,05$ dan nilai thitung 3,893 > t tabel 2,1098, sehingga dapat di simpulkan bahwa H1 diterima yang berarti terdapat pengaruh Kegunaan terhadap Interaksi

2. Hipotesis Kedua, Diketahui nilai Sig. untukpengaruh Kegunaan terhadap Interaksi adalah sebesar 0,696 > 0,05 dan nilai t hitung 0,397 < t tabel 2,1098, sehingga dapat di simpulkan bahwa $\mathrm{H} 2$ ditolak yang berarti tidak terdapat pengaruh Informasi terhadap Interaksi

3. Hipotesis Ketiga, Diketahui nilai Sig. untuk pengaruh Kegunaan dan Informasi secara simultan terhadap Interaksi adalah sebesar 0,015

$<0,05$ dan nilai f hitung $23.978>\mathrm{t}$ tabel 3,59, sehingga dapat di simpulkan bahwa H3 diterima yang berarti terdapat pengaruh Kegunaan dan Informasi terhadap Interaksi

Dalam memenuhi kebutuhan para pengguna, sangat bergantung pada kemudahan, keamanan, informasi yang 
diperoleh dan pelayanan yang tersedia pada website. Karena itu untuk dapat memperoleh penilaian yang positif dari parapengguna web, pengembang diharapkan lebih memperhatikan factor-faktor mengenai kepuasan pengguna

\section{REFERENCES}

Chmielarz, W., \& Zborowski, M. (2018). Analysis of e-Banking Websites' Quality with the Application of the TOPsIs Method - A Practical study. Procedia Computer Science, 126, 1964-1976. https://doi.org/10.1016/j.procS.2018.07.256

Connolly, R., Bannister, F., \& Kearney, A. (2010). Government website service quality: A study of the Irish revenue online service. European Journal of Information Systems, 19(6), 649667. https://doi.org/10.1057/ejis.2010.45

Dyatmika, S. W. (2018). Pengaruh Kualitas Informasi Dan Persepsi Resiko Terhadap Keputusan Pembelian Pada Tokopedia. Majalah Ekonomi, XXIII(1411), 124-134.

Pathania, A., \& Rasool, G. (2017). Investigating e tailer's perceived Website Quality using Analytical Hierarchy Process Technique. Procedia Computer Science, 122, 1016-1023. https://doi.org/10.1016/j.procs.2017.11.468

Rahayu, L. K., Mustika, W. P., \& Wahyudi, W. F. (2018). E-Commerce Alzafa . Com Terhadap Keputusan Pembelian Online. Journal of Information System, Applied,Management,Accounting andResearch, 2(1), 47-54.

Wahyuni, R. T., Herawatie, D., \& Justitia, A. (2017). Analisis Kualitas Layanan Website Pusat Penerimaan Mahasiswa Baru Universitas Airlangga Berdasarkan Persepsi Pengguna Menggunakan Metode Webqual 4.0 danImportance Performance Analysis (IPA). Seminar Nasional Matematika Dan Aplikasinya, 408-418.

Zamani, U. I., Sunarto, D., \& Mastan, I. A. (2016). Analisi Pengaruh Kualitas Website PT Badak LNG Terhadap Kepuasan Pengguna Menggunakan Metode Webqual 4.0. Jurnal JSIKA, 5(11), 1-8. https://jurnal.stikom.edu/index.php/jsika/article / view/1387 